Mijo Galiot, sudac

Općinskog suda u Splitu

član Državnog sudbenog vijeća

\title{
OSNOVNE ZNAČAJKE KAZNENOPRAVNE ZAŠTITE PROTIV KORUPCIJE U TALIJANSKOM ZAKONODAVSTVU, DOKTRINI I SUDSKOJ PRAKSI
}

\author{
UDK: 342 (450) \\ Primljeno: 1.05. 2016. \\ Pregledni rad
}

Politika sprečavanja činjenja kaznenih djela, a poglavito korupcijskih djela u koje spada i davanje mita kao tipično takvo djelo, od izuzetne je važnosti za svaki uređeni pravni sustav. Središnji dio te politike predstavlja kaznenopravna politika. $O$ uspješnosti te politike umnogome ovisi cjelokupan politički i gospodarski razvoj svake pojedine zemlje. U prilog znanstvenoj raspravi, a s ciljem da bi domaća kaznena politika suzbijanja korupcijskih kaznenih djela bila što učinkovitija, u radu se analizira kazneno zakonodavstvo Republike Italije s obzirom na pitanje aktivnog podmićivanja kao jednog od temeljnih oblika koruptivnog ponašanja. Prikazujući komparativno uređenje talijanskog kaznenog sustava, koji, kao i hrvatski, pripada europskim kontinentalnim kaznenim pravnim sustavima, autor će se osvrnuti na temeljne sličnosti i razlike pravnog uređenja aktivnog podmićivanja u Republici Italiji u odnosu na domaći pravni sustav.

Ključne riječi: dar; mito, druga korist; korupcija; organizirani kriminalitet; davanje mita; kažnjavanje; svrha kažnjavanja; kazna; kazna zatvora; kazneni postupak; kaznene sankcije

\section{UVOD}

\subsection{Načelno}

Talijansko, baš kao i hrvatsko kazneno pravo odražava značajke tipične za nacionalna kaznena prava europskih kontinentalnih država. Osnovna je takva značajka utemeljenost kaznenog prava na (pisanom) kaznenom zakonu. ${ }^{1}$ Tako je $\mathrm{i}$ talijansko kazneno pravo utemeljeno na kaznenom zakonu (Codice penale, $\mathrm{u}$ daljnjem tekstu: $\mathrm{CP})^{2}$ kojim je utjelovljeno načelo zakonitosti kaznenog prava. To

1 Usp. Novoselec, Petar; Bojanić, Igor: Opći dio kaznenog prava, IV. izd., Zagreb, 2013., str. 63 i 67.

2 Codice penale (trenutno važeći) talijanski Kazneni zakonik, koji je u definitivnom tekstu objavljen u Službenom glasilu (Gazzeta Ufficiale) Kraljevine Italije broj 251 od 26. listopada 1930., zajedno sa svim kasnijim izmjenama i dopunama (u daljnjem tekstu: $\mathrm{CP}$ ). 
je načelo propisano u odredbama iz članka 25. Ustava Republike Italije ${ }^{3}$ i članka 1. CP-a koje su, kako po sadržaju, tako i po svrsi, posve usporedive s odredbama iz članka 31. Ustava Republike Hrvatske i članka 2. KZ-a.

Dosljedno tomu, posebni dio CP-a, baš kao i posebni dio KZ-a, sadrži odredbe koje inkriminiraju (aktivno) podmićivanje (korupciju). Te su odredbe pripadne I. odsjeku glave II. CP-a koja nosi naslov „O kaznenim djelima protiv javne uprave“ („Dei delitti contro la pubblica amministrazione"), a podijeljena je na navedeni I. odsjek, naslovljen „O kaznenim djelima službenih osoba protiv javne uprave“ (,Dei delitti dei pubblici ufficiali contro la pubblica amministrazione"), na II. odsjek, naslovljen „O kaznenim djelima privatnih osoba protiv javne uprave“ (,Dei delitti dei privati contro la pubblica amministrazione") i III. odsjek, naslovljen „Odredbe koje su zajedničke prethodnim odsjecima“ (, Disposizioni comuni ai capi precedenti").

\subsection{Ciljevi istraživanja}

Temeljni cilj autora sastojao se u tome da se u ovom radu dade pregled i analiziraju osnovne značajke inkriminiranja i kaznenopravnog sankcioniranja (aktivnog) podmićivanja (korupcije) u (pozitivnom) talijanskom kaznenom pravu.

Početno se, kratko i uvodno, izlaže o značajkama, pravnim pojmovima te o kaznenopravno zaštićenom dobru koji su zajednički svim inkriminacijama iz navedenog I. odsjeka II. glave CP-a kojemu pripadaju i inkriminacije podmićivanja (korupcije).

Nadalje, težište analize „prebačeno“ je na izlaganje o tzv. minisustavu korupcijskih kaznenih djela te se daje pregled glavnih odrednica doktrinarnog i sudskog tumačenja vezano za propisane oblike kaznenog djela (aktivnog) podmićivanja (korupcije).

I najzad, prikazuje se sustav zakonom zapriječenih kaznenopravnih sankcija za ova kaznena djela. Navedenim slijedom, dotiče se i bližu povijesnopravnu genezu odnosnih inkriminacija i kaznenopravnih sankcija, svugdje gdje je to relevantno za razumijevanje vladajućih shvaćanja i tumačenja kaznenopravne doktrine i sudske prakse.

Costituzione della Republika Italiana (trenutno važeći) talijanski Ustav, objavljen u Službenom glasilu (Gazzeta Ufficiale) broj 298 od 27. prosinca 1947., sa svim kasnijim izmjenama i dopunama (u daljnjem tekstu: Ustav Talijanske Republike). 


\section{DAVANJE MITA U TALIJANSKOJ REPUBLICI}

\subsection{Zakonski okvir}

Kako je i uvodno kazano, poput hrvatskog pravnog sustava, tako je i talijansko kazneno pravo utemeljeno na kaznenom zakonu odnosno odredbama CP-a.

Posebni dio CP-a, baš kao i posebni dio KZ-a, sadrži odredbe koje inkriminiraju (aktivno) podmićivanje (korupciju).

Izlaganje osnovnih značajki normativnog okvira započet ćemo s dvije doktrinarne opaske koje se tiču samog naslova I. odsjeka glave II. CP-a, koji glasi „O kaznenim djelima službenih osoba protiv javne uprave“ (,Dei delitti dei pubblici ufficiali contro la pubblica amministrazione"). U doktrini se iznose kritike da je takvim naslovljavanjem ovog odsjeka propušteno pokriti sav njegov sadržaj. Ove su kritike usredotočene na problem značenja izraza ,i pubblici ufficiali“ (,službene osobe“) u kontekstu tog naslova, u vezi s čime prigovaraju da ni sintetičko (najšire) značenje toga izraza ne otklanja problem parcijalnosti tog naslova.

Radi se o tomu da značenje izraza ,, i pubblici ufficiali“ (,službene osobe“) iz tog naslova nije dostatno uzeti samo u normativnom (užem) smislu tj. onako kako taj izraz definira njegova zakonska definicija iz članku 357. CP-a jer je jedino njegovo sintetičko (najšire) značenje najbliže obuhvaćanju svih osoba koje se mogu pojaviti kao počinitelji svih kaznenih djela zakonski opisanih u tom odsjeku. To sintetičko (najšire) značenje izraza ,i pubblici ufficiali“ („službene osobe“) obuhvaćalo bi, dakle, pored osoba iz navedene odredbe članka 357. CP-a, još i osobe iz odredaba članaka 358. („persone incaricate di un pubblico servizio“ - osobe kojima je povjerena javna služba) i 359. CP-a (,persone esercenti un servizio di pubblica necessità “ - osobe koje obavljaju javno nužne službe), kao i posebne kategorije službenih osoba prema talijanskim pozitivnim službeničkim propisima, pri čemu se u prvom redu misli na službenike u redarstvenim i u oružanim snagama. No, ni tako uzetim sintetičkim (najširim) značenjem izraza ,i pubblici ufficiali“ (,službene osobe") još ne bi bio obuhvaćen krug svih počinitelja svih inkriminacija iz tog tako naslovljenog odsjeka CP-a.

Stoga se prigovara i parcijalnosti tog naslova, koju se vidi u tomu što i prethodno izloženi sintetički (najširi) smisao izraza ,i pubblici ufficiali“ (,službene osobe“) iz tog naslova još ne obuhvaća sve počinitelje svih kaznenih djela propisanih u tom odsjeku, u vezi s čime se navodi baš primjer aktivnog podmićivanja kod kojega se kao počinitelj pojavljuje privatna osoba koja je, kao takva, nepodvediva pod pojam „, pubblici ufficiali“" (,službene osobe“"). ${ }^{4}$

4 Tako Ronco, Mauro; Romano, Bartolomeo: Codice Penale Commentato, IV. ed., UTET, 2012., str. 1536 


\subsection{O pojmovima službena osoba i osoba kojoj je povjerena javna služba}

\subsubsection{Pojam službene osobe}

Na tragu potonje iznesenoga, zadržavamo se na pitanjima pravnog značenja pojma ,i publicci ufficiali“ (,službene osobe“), pojma „persona incaricata di un pubblico servizio“(„osoba kojoj je povjerena javna služba“), te pravnog dobra koje se štiti inkriminacijama iz ovog odsjeka, s obzirom na to da su ova pitanja od uvodne važnosti za problematiku kaznenopravne zaštite protiv (aktivnog) podmićivanja (korupcije).

Kaznenopravno značenje pojmova ,i publicci ufficiali“ i ,persona incaricata di un pubblico servizio" određuju norme - definicije tih pojmova koje su sadržane u odredbama iz članaka 357. i 358. CP-a.

Tako odredba iz članka 357. CP-a propisuje da su, u smislu kaznenog zakonodavstva, ,i publicci ufficiali“ (,službene osobe“) one osobe koje obnašaju javnu dužnost u zakonodavnoj, sudbenoj i izvršnoj vlasti, s čim je, kao javna dužnost, izjednačeno i obavljanje upravne djelatnosti kojom se, u skladu s normama javnog prava i općenormativnim aktima, oblikuje i izražava volja javne uprave, ili donose pojedinačni upravni akti, ili izdaju potvrde koje uživaju javnu vjeru.

U doktrini se ističe da izložena odredba sada propisuje objektivno-funkcionalnu definiciju službene osobe, za razliku od formalno-objektivne definicije službene osobe koja je bila propisana prije izmjene CP-a iz $1990 .{ }^{5}$ Ova objektivnofunkcionalna definicija se, za razliku od one čisto objektivne, ne iscrpljuje samo u objektivnom elementu odnosa pripadnosti te osobe organizaciji države, nego uvodi još i funkcionalni element obavljanja takve dužnosti ili djelatnosti koja ima javnu narav. Recentnija sudska praksa baš ide u korist ovog funkcionalnog, a na uštrb objektivnog elementa. Tako se funkcionalni element naglašava kroz ustaljena shvaćanja recentnije sudske prakse prema kojima: mora se raditi o obavljanju takve djelatnosti koja je podvrgnuta normama javnog ili upravnog prava (C., Sez. VI., 21. III. 2003.), pri čemu se može raditi čak i o takvoj djelatnosti koja je samo sporednog i konzultativnog značaja i, kao takva, lišena izravnog učinka po treće osobe ili vanjskog značaja (C., Sez. VI., 10. II. 2004.), te o takvoj djelatnosti u kojoj je počinitelj imao udjela u bilo kojem trenutku tijeka njezina unutarnjeg odvijanja prije onog trenutka u kojem je izražena spram van kao akt volje javne uprave. Istovremeno, umanjivanje važnosti objektivnog elementa u sudskoj praksi ide sve do shvaćanja da je, u izostanku pravne egzistencije tog elementa, dostatna samo njegova nedvojbena činjenična egzistencija. Tu se radi o slučajevima u kojima je sudska praksa svojstvo službene osobe priznavala i osobama koje su javnu dužnost obavljale po osnovi prešutnog odobrenja, a bez donesenog propisanog akta o njihovu izboru ili imenovanju na tu dužnost, uz uvjet da se ne radi o uzurpiranju te dužnosti (C., Sez. VI., 19. IX. 1995.).

5 Radi se o izmjenama i dopunama koje je propisao Zakon broj 86. od 26. travnja 1990. (u daljnjem tekstu: izmjene CP-a iz 1990.). 
Što se tiče osoba koje obavljaju upravnu djelatnost, doktrina je suglasna da citirana odredba iz članka 357. CP-a ima u vidu samo osobe koje obavljaju klasičnu upravnu djelatnost, shvaćenu u smislu donošenja općenormativnih akata uprave i pojedinačnih upravnih akata te izdavanja potvrda koje uživaju javnu vjeru, a nema u vidu osobe koje obavljaju koju od javnih službi.

Za ilustraciju sudskog tumačenja odredbe iz članka 357. CP-a, izdvajamo sljedeće primjere ustaljenog priznavanja svojstva službene osobe u sudskoj praksi: članovima parlamenta i predstavničkih tijela regija (C., Sez. VI., 30. XI. 2005.), članovima predstavničkih tijela komuna (C., Sez. VI., 18. I. 1974.), sucima redovitih i upravnih sudova te javnim tužiteljima (C., Sez. V., 26. II. 2008.), sudskim službenicima (C., Sez. VI., 24. IX. 1998.), djelatnicima tehničke i pomoćne službe pravosudne i zatvorske policije (C., Sez. VI., 28. X. 1997.; C., Sez. VI., 07. I. 1999.), sudskom ovršitelju (C., Sez. VI., 14. X. 2008.), svim pripadnicima oružanih i redarstvenih snaga (C., Sez. I., 12. VI. 2000.; C., Sez. I., 10. VI. 1986.), čelnicima i službenicima u upravnim tijelima regija i komuna (C., Sez. VI., 02. IV. 2009.; C., Sez. VI., 08. III. 1995.), službenicima sveučilišta koji u sveučilišnim stvarima donose pojedinačne upravne akte i izdaju potvrde koje uživaju javnu vjeru (C., Sez. VI., 26. III. 1997.). Spomena je vrijedno i priznavanje tog svojstva svim nastavnicima u državnim školama i privatnim školama s pravom javnosti (C., Sez. V., 13. I. 1999.; C., Sez. II., 11. II. 1992.) u pogledu čega je iskazano i suprotno mišljenje (C., Sez. VI., 26. III. 1997.). ${ }^{6}$

Na podlozi prethodno izloženih shvaćanja doktrine i sudske prakse, može se zaključiti da se kaznenopravno značenje pojma ,,i publicci ufficiali“ (,službene osobe“), kako ga određuje odredba iz članka 357. CP-a, u suštini svodi na kategorije državnih dužnosnika i državnih službenika shvaćene u njihovu klasičnom značenju, pa tako opseg tog pojma seže do (fluidne) crte razgraničenja državne vlasti i uprave od javnih službi.

U tom smislu, i doktrina u navedenoj odredbi članka 357. CP-a ne vidi (samo) neposrednu kaznenopravnu definiciju pojma ,i publicci ufficiali“ (službene osobe), nego vidi (još) i posrednu kaznenopravnu definiciju pojma javne uprave (,la publicca amministrazione"). Tako se u doktrini navodi da je kaznenopravni pojam javne uprave širi od onoga kojim operiraju ustavna i upravnopravna znanost, koje taj pojam svode samo na tijela državne uprave odnosno na upravnu djelatnost, dok u kaznenopravnom smislu taj pojam ne obuhvaća samo tijela državne uprave odnosno samo upravnu djelatnost, nego još i tijela državne (zakonodavne, sudbene i izvršne) vlasti, a time i svu političku, sudsku i upravnu djelatnost države uzetu u njezinoj ukupnosti. $^{7}$

6 Usp. op. cit. (bilj. 2), str. 1851-1855; Primo Triolo, Dario: Ireati contro la pubblica amministrazione, KEY SRL, 2015., str. 10-17.; Carcano, Domenico: Manuale di Diritto Penale - Parte Speciale, Giuffrè Ed., 2010., str. 95-104.

Tako Vinciguerra, Sergio: I delitti contro la pubblica amministrazione, CEDAM, 2008., str. 3-4; Atolisei, Francesco: Manuale di Diritto Penale - Parte Speciale II, 15. ed. Giuffrè Ed.., 2008., str. 284285; Primo Triolo (op. cit. bilj. 3) str. 9. 


\subsubsection{Osoba kojoj je povjerena javna služba}

Odredba iz članka 358. CP-a propisuje da je u smislu kaznenog zakonodavstva „persona incaricata di un pubblico servizio“ (,osoba kojoj je povjerena javna služba“) svaka ona osoba koja po bilo kojoj osnovi obavlja javnu službu, a javnom službom da se ima smatrati ona aktivnost koja jest uređena u istom obliku kao i javna dužnost, ali nema ovlaštenja tipična za ovu potonju, nego se sastoji u obavljanju jednostavnijih zadaća u poretku i materijalnih radnji.

I u pogledu ove norme definicije, u doktrini se ističe kako je izmjena CP-a iz 1990. pribjegla objektivno-funkcionalnom pojmu javne službe, tako što je naglasak stavila na samu funkciju obavljanja javne službe po bilo kojoj osnovi, i napustila ranije propisani formalno-objektivni koncept javne službe koji je isticao objektivni odnos između osobe koja je obavlja i državnih odnosno javnih tijela. Stoga se, za kaznenopravno poimanje javne službe, u smislu kako je uređeno sada važećim člankom 358. CP-a, u doktrini ističe kako nije odlučno da se radi o službi koju obavlja javni subjekt nego je odlučno da se radi o službi koju se ne obavlja prvenstveno u privatnom nego prvenstveno u javnom interesu. Na tom je tragu i shvaćanje iz sudske prakse po kojem javna služba podrazumijeva djelatnost uređenu javnopravnim normama i usmjerenu na ukupnost svih građana (Cass., 2. XII. 2003.).

Sudska je praksa u primjeni članka 358. CP-a priznala svojstvo osobe koja obavlja javnu službu, primjerice: osobi koja po osnovi dobivene koncesije obavlja bilo koju službu koja je javnopravnom normom određena kao javna služba (Cass., 13. VII. 1998.), poštaru u Talijanskim poštama (Cass. 27981/11), zaštitaru (Cass. 49537/14), pružatelju usluge javnog parkirališta (Cass. 14. I. 2009.), radniku koji u trgovačkom društvu za telekomunikacije obavlja poslove računalne registracije ostvarenog telekomunikacijskog prometa (Cass. 12. VII. 2004.), osobi koja upravlja sredstvom javnog prijevoza (Cass. 22. XI. 1996.), voditelju odlagališta komunalnog otpada (Cass., Sez VI., 07. III. 2000.), radniku trgovačkog društva nastalog privatizacijom državnih željeznica (Cass., Sez VI., 02. VII. 1998.), radniku trgovačkog društva nastalog privatizacijom državnih pošta (Cass. 21. III. 2003.), ljekarniku (Cass., 22. II. 1991.), te članovima uprave javne televizije RAI. ${ }^{89}$

Navedeni stavovi i doktrine i sudske prakse ukazuju na poprilično ekstenzivno tumačenje navedene odrednice iz članka 358. CP-a.

S prethodnim je u vezi i regulativa iz odredbe članka 360 . CP-a, koja razrješava situaciju kada je (kaznenopravno relevantno) svojstvo službene osobe ili osobe kojoj je povjerena javna služba otpalo prije ili u trenutku dovršenja kaznenog djela. Prema toj odredbi, kada zakon propisuje, svojstvo službene osobe ili osobe kojoj je povjerena javna služba ili osobe koja obavlja javno nužnu službu, kao bitno obilježje kaznenog djela, ili kao otegotnu okolnost, tada prestanak tog svojstva, u

8 Potonje se shvaćanje sudske prakse navodi u Carcano (op. cit. bilj. 3), str. 109, bez podataka o sudskoj odluci ili sentenci.

9 Usp. Carcano (op. cit. bilj. 3) str. 107-110; Primo Triolo (op. cit. bilj. 3) str. 17-21. 
vrijeme kada je to kazneno djelo počinjeno, ne isključuje postojanje tog kaznenog djela ni te otegotne okolnosti ukoliko se tiče prethodno obavljane službe.

Po pitanju pravnog dobra koje se štiti propisivanjem kaznenih djela protiv javne uprave, suvremena doktrina je, pogotovo nakon izmjene CP-a iz 1990., gotovo suglasno napustila starije doktrinarno shvaćanje koje je zaštićenim objektom smatralo samu organizaciju države odnosno državne (javne) uprave. Nasuprot tomu, novija su doktrinarna shvaćanja sklona tumačenjima da je zaštitna svrha ovih inkriminacija usmjerena na pravna dobra pravičnosti (,buon andamento“) i nepristranosti (l'imparzialità) u radu javne uprave i njezina isključivog služenja narodu (,servizio esclusivo della Nazione“) koja propisuju odredbe iz članaka 97. i 98. Ustava Republike Italije. Ova novija doktrinarna shvaćanja stavlja se u njihov širi kontekst koji treba tražiti u učenjima politoloških i javnopravnih znanosti o „novoj upravi“". Ta su učenja odjek osebujnog poslijeratnog razvoja regulative, znanosti i prakse ljudskih prava i temeljnih sloboda. Sadržaj tih učenja svodi se na prebacivanje težišta sa hijerarhije na koordinaciju u unutarnjim odnosima u upravi, uz istovremeno prebacivanje težišta sa autoritativnosti uprave na uvažavanje temeljnih sloboda i prava građana u vanjskom odnosu uprave spram građana. ${ }^{10}$

\subsection{Kaznenopravna zaštita protiv aktivnog podmićivanja prema $\mathrm{CP}-\mathrm{u}$}

Nakon ovih uvodnih razmatranja, u nastavku se analizira kaznenopravna zaštita protiv (aktivnog) podmićivanja.

\subsubsection{Osnovni oblici aktivnog i pasivnog podmićivanja}

Prije svega je potrebno ukazati na terminološku okolnost da je, za sve opće i posebne oblike kaznenih djela aktivnog i pasivnog podmićivanja, u talijanskoj zakonskoj terminologiji, doktrini i sudskoj praksi uvriježen naziv „korupcijska kaznena djela“". ${ }^{11}$ Govori se tako o tzv. ,jedinstvenom minisustavu korupcijskih kaznenih djela"12 koji se iščitava iz ukupnosti odredaba sadržanih u člancima 318. do 322-quater CP-a. Pravi se i razlika između općeg (članci 318., 319., 320. i 321.) i posebnog (članci 319-ter, 322. i 322-bis) dijela tog minisustava, te onog njegova dijela koji sadrži odredbe o kaznenopravnim sankcijama i njihovu sudskom odmjeravanju (članci 319.-bis, 322-ter i 322-quater CP-a). ${ }^{13}{ }^{14}$ Prihvaćamo ovo razlikovanje kao pogodno za sistematizaciju daljnjeg izlaganja.

10 Usp. Vinciguerra (op. cit. bilj. 7) str. 16-17; op.cit. (bilj. 4) str. 285.

11 Stoga u nastavku dosljedno koristimo izraz korupcija u značenju podmićivanje.

12 V. Lattanzi, Giorgio; Lupo, Ernesto: Codice Penale - Rassegna di giurisprudenza e di dottrina, Vol. VII., Libro II, Giuffrè Ed., 2010., str. 139.

13 Usp. op. cit. (bilj. 2), str. 1621.

14 U vezi s navedenim odredbama CP-a koje tvore tzv. jedinstveni minisustav korupcijskih kaznenih djela, u doktrini se ističe kako je njihov koncept, kako je uspostavljen odredbama CP-a iz 1930., ostao kontinuiran. Ovaj dio CP-a u novije je vrijeme triput opsežnije mijenjan. Pritom se, kao posebno opsežne, ističu izmjene iz 1990. Te su izmjene stvorile zakonsku podlogu za stupanje u poznatu policijsko- 
Dajemo sada redom prijevod svih navedenih odredba CP-a koje tvore opći dio tzv. minisustava korupcijskih kaznenih djela, prema važećoj verziji, i uz osvrt na njihovu bližu povijesnopravnu genezu.

Članak 318. CP-a nosi naslov „Korupcija za izvršavanje funkcije“ i propisuje da će se službena osoba koja, za izvršavanje svojih funkcija ili svojih ovlasti, neovlašteno primi, za sebe ili za treću osobu, novac ili kakvu drugu korist, ili prihvati obećanje iste, kazniti kaznom zatvora u od jedne do šest godina.

Izloženu važeću verziju članka 318. CP-a čini zakonski opis kaznenog djela kako je propisan izmjenom CP-a iz 2012., i kaznenopravna sankcija kako je propisana izmjenom CP-a iz 2015. Prije izmjene CP-a iz 2012., članak 318. CP-a nosio je naslov „Korupcija za izvršavanje službene radnje“ i propisivao je, u stavku 1., da će se službena osoba koja, za izvršenje radnje iz svoje službe, primi, za sebe ili za treću osobu, u novcu ili drugoj koristi, retribuciju koja nije dugovana, ili prihvati obećanje iste, kazniti kaznom zatvora od šest mjeseci do tri godine; a u stavku 2., kaznu zatvora do jedne godine ako službena osoba primi retribuciju za službenu radnju koju je već izvršila. Prije izmjene CP-a iz 2015., u članku 318. CP-a bila je propisana kazna zatvora od jedne do pet godina.

Članak 319. CP-a nosi naslov „Korupcija za radnju protivnu obvezama službe“ i propisuje da će se službena osoba - koja, da bi propustila ili odgodila, ili za propuštenu ili odgođenu radnju iz svoje službe; ili da bi izvršila, ili za izvršenu radnju protivnu obvezama službe; primi, za sebe ili za treću osobu, novac ili drugu korist, ili prihvati obećanje iste - kazniti kaznom zatvora od šest do deset godina.

Izloženu važeću verziju članka 319. CP-a čini zakonski opis kaznenog djela kako je propisan izmjenom CP-a iz 1990. i otada nije mijenjan. Mijenjana je jedino mjera kazne zatvora koja je izmjenom CP-a iz 1990. bila propisana u trajanju od dvije do pet godina, dok je izmjenom CP-a iz 2012. bila propisana u trajanju od četiri do osam godina.

Članak 320. CP-a nosi naslov „Korupcija osobe kojoj je povjerena javna služba“ $i$ propisuje, u stavku 1., da se odredbe članaka 318. i 319. primjenjuju i na osobu kojoj je povjerena javna služba, a u stavku 2., da se u svakom slučaju kazne ublažavaju u mjeri ne većoj od jedne trećine.

Izložena važeća verzija članka 320. CP-a propisana je izmjenom CP-a iz 2012. Prije te izmjene, članak 320. propisivao je da se odredbe iz članka 319. primjenjuju i na osobu kojoj je povjerena javna služba, a odredbe iz članka 318. da se primjenjuju na osobu kojoj je povjerena javna služba kada ima svojstvo javnog službenika.

tužiteljsko-sudsku akciju obračuna s korupcijom pod nazivom „mani pulite“. Nešto su opsežnije i izmjene iz 2012. (Zakon broj 190 od 6. studenog 2012., u daljnjem tekstu: izmjene CP-a iz 2012.) kojima se također diralo, kako u zakonske propise, tako i u propisane kaznenopravne sankcije za korupcijska djela. Manje su opsežne jedino izmjene iz 2015. (Zakon broj 69 od 27. ožujka 2015., dalje u tekstu: izmjene CP-a iz 2015.) koje su se, za razliku od prethodnih, ticale jedino propisanih kaznenopravnih sankcija.

V. i Guerrini, Roberto; Guidi, Dario: Bribery in Italy - an outlook on present laws and perspectives on reform; Modern Bribery Law - Comparative perspectives, Cambridge University Press 2013., str. $113-116$. 
Najzad, članak 321. CP-a, u važećoj verziji, kako je propisana izmjenom CP-a iz 1990., naslovljen je „Kazne za koruptora“ i propisuje da se kazne propisane u članku 318. stavak 1., u članku 319., u članku 319-bis, u članku 319-ter, i u članku 320. u svezi sa člancima 318. i 319., primjenjuju i na onoga koji dade ili obeća službenoj osobi ili osobi kojoj je povjerena javna služba novac ili drugu korist.

\subsubsection{Opće doktrinarne i praktične značajke tzv. jedinstvenog minisustava korupcijskih kaznenih djela}

U nastavku, iznose se opće doktrinarne i praktične značajke u vezi s prethodno izloženim odredbama koje tvore opći dio tzv. jedinstvenog minisustava korupcijskih kaznenih djela.

Prvo, talijanska doktrina i sudska praksa barataju tipičnim i uvriježenim parnim klasifikacijama kod kaznenih djela korupcije, razlikujući tako:

- nepravu (članak 318. CP-a u vezi s člancima 320. i 321. CP-a) i pravu (članak 319. CP-a u vezi s člancima 320. i 321. CP-a) korupciju,

- pasivnu (članci 318., 319. i 320. CP-a) i aktivnu (članci 318., 319. i 320. CP-a u vezi s člankom 321. CP-a) korupciju, i

- prethodnu (članci318.i 319. u vezi s člancima 320.i321. CP-a) i naknadnu (članak 319. CP-a u vezi s člancima 320. i 321. CP-a) korupciju. ${ }^{15}$

Drugo, što se tiče pravnoga dobra koje se štiti prethodno izloženim korupcijskim inkriminacijama, u doktrini se pravi razlika između tzv. statičnih i dinamičkih teorija. Statične su teorije starijeg datuma. Polaze od toga da je objekt zaštite samo biće državnih organa odnosno javne uprave. Pod statične se teorije podvode i učenja o tome da se korupcijskim inkriminacijama štiti odnos vjernosti dužnosnika odnosno službenika spram dužnosti odnosno službe, dignitet državnih organa i državne službe, te nepotkupljivost službenika i dužnosnika. S druge strane, dinamičkim je teorijama temeljna i zajednička postavka da je objekt zaštite čin države odnosno javne uprave. Ove su teorije novijeg datuma. Uglavnom se inspiriraju prethodno izloženim učenjima koja zaštitnu svrhu svih inkriminacija iz I. odsjeka glave II. $\mathrm{CP}-\mathrm{a}$, pa time i korupcijskih inkriminacija, fiksiraju na pravna dobra pravičnosti (,,buon andamento") i nepristranosti (l'imparzialità) u radu javne uprave i njezina isključivog služenja narodu (,servizio esclusivo della Nazione“) koja su propisana člancima 97. i 98. Ustava Talijanske Republike. U doktrini je prisutna i podjela na tzv. teleološki i analitički pristup zaštićenom dobru kod korupcijskih inkriminacija. Teleološki se pristup zasniva na svrsi (cilju) kaznenopravne zaštite koju vidi u sprečavanju privatizacije službe i zaštiti obavljanja službe u isključivo javnom interesu. S druge strane, uvidi analitičkog pristupa razlikuju pravu od neprave korupcije baš po kriteriju zaštićenih dobara, deduktivne su logičke strukture, pa time i konkretniji odnosno manje uopćeni, a svode se na jednostavnu te u doktrini i sudskoj praksi neprijepornu tvrdnju da se inkriminiranjem neprave korupcije štite

15 Za prihvaćanje ovih podjela, samo primjerice, v. op. cit. (bilj. 2) str. 1621-1622; Vinciguerra (op. cit. bilj. 7), str. 193-195, Guerrini, Guidi (op. cit. bilj. 14), str. 102-104. 
Mijo Galiot: Osnovne značajke kaznenopravne zaštite protiv korupcije u talijanskom zakonodavstvu... Zbornik radova Pravnog fakulteta u Splitu, god. 54, 2/2017., str. 503.- 531.

nepotkupljivost i neprivatiziranje službe, dok se inkriminiranjem prave korupcije pored toga štiti još i pravilno obavljanje službe. ${ }^{16}$

Treće, učenje o korupcijskom dvostranoobveznom kauzalnom ugovoru bitno je odredilo, kako doktrinarne stavove, tako i stavove sudske prakse u pogledu korupcijsih inkriminacija. U najkraćim crtama, radi se o ugovoru koji sklapaju, s jedne strane službena osoba ili osoba kojoj je povjerena javna služba (javni agent, tzv. intraneus), te s druge strane privatna osoba (koruptor, tzv. extraneus). Subjektivni se element kod toga ugovora očituje u susretu slobodnih volja njegovih stranaka. Objektivni je element toga ugovora sadržan u svrsi (kauza) koja se ima postići ispunjenjem stranačkih obveza. Ta je svrha razmjenska odnosno kupoprodajna. Razmjenjuje se (prodaje) radnja iz službe ili radnja protivna obvezi iz službe (činidba koju službeni subjekt duguje privatnome) za novčani iznos ili drugu korist (činidba koju privatni subjekt duguje službenome). Ugovor je sklopljen kada subjekt koji je ponuđen prihvati koruptivnu ponudu koju mu je stavio subjekt koji je ponuditelj, pri čemu nije odlučno koji se subjekt nalazi u ulozi ponuđenog odnosno ponuditelja. Ugovor je izvršen ispunjenjem prethodno navedenih stranačkih činidaba iz tog ugovora. Ovaj civilistički koncept kauzalnog ugovora bitno je odredio talijansku doktrinu i sudsku praksu u vezi s korupcijskim kaznenim djelima. Tako nije rijetkost da se u presudama postojanje pojedinih elemenata iz bića korupcijskog kaznenog djela obrazlaže u ključu ovog koncepta. ${ }^{17}$ Isto tako je tragom tog koncepta često išla, kako doktrinarna, tako i sudska interpretacija prilikom razrješavanja prijepornih pravnih pitanja kod korupcijskih inkriminacija, o čemu će biti riječi u nastavku ovog izlaganja. Opisanu važnost ovog koncepta oslikava i to što se na njemu zasnivaju i sve preostale opće značajke (četvrta, peta i šesta) koje neposredno navodimo u nastavku. ${ }^{18}$

Četvrto, a što se tiče odnosa aktivne i pasivne korupcije, u doktrini je dominantno, i u sudskoj praksi prihvaćeno, shvaćanje prema kojemu je korupcijsko kazneno djelo jedno posebno i bilateralno kazneno djelo koje karakterizira nužno sudioništvo supočiniteljskog tipa između službene osobe ili osobe kojoj je povjerena javna služba i privatnog subjekta (koruptora). Dakle, prema prevladavajućem doktrinarnom, i u sudskoj praksi posve prihvaćenom shvaćanju, kod aktivne i pasivne korupcije ne radi se o pluralitetu kaznenih djela nego se radi o nužnom pluralitetu osoba (sudioništvu) u jednom kaznenom djelu. Tomu u prilog se, kao glavni doktrinarni razlozi, ističu navedeni koncept dvostranog kauzalnog korupcijskog ugovora, kao i to da je odredba iz članka 321. CP-a stipulirana na način da niti ne sadrži zakonski opis aktivne korupcije nego samo propisuje proširenje kažnjavanja i na

16 Za izložena učenja o pravnom dobru koje se štiti korupcijskim inkriminacijama v. op. cit. (bilj. 2) str. 1624-1625 i 1659; Carcano (op. cit. bilj. 3), str. 156; Antolisei (op. cit. bilj. 4), str. 350-351 i 354-355; Ponti, Alberto: I principali delitti contro la Pubblica Amministrazione, HALLEY, 2002., str. 35; op. cit. (bilj. 8) str. 139 i 162; Guerrini, Guidi, (op. cit. bilj. 14), str. 100-105.

17 Tako se, primjerice, pomalo apstraktno obrazlaže kako je ,izvršenje radnje protivne obvezama službe bilo kauza protučinidbe prepuštanja koristi i njenog prihvata od strane službene osobe“ u C. Sez. VI., 25. III. 2010., v. (op. cit. bilj. 2), str. 1628.

18 V. (op. cit. bilj. 2), str. 1627-1628; Antolisei (op. cit. bilj. 4) str. 343; Vinciguerra (op. cit. bilj. 7), str. 191-193, (op. cit. bilj. 8), str. 179 i 182; (op. cit. bilj. 14), str. 111. 
aktivnu korupciju odnosno na privatnog subjekta (koruptora). ${ }^{19}$ Primjećujemo nemalu proturječnost u koju ovo shvaćanje upada kada istovremeno „čuva“ narav korupcijskog kaznenog djela kao posebnog kaznenog djela (delictum proprium) i na rang supočinitelja stavlja koruptora koji nema propisano svojstvo (službene osobe ili osobe kojoj je povjerena javna služba). U doktrini je prisutno i (manjinsko) suprotno shvaćanje prema kojem se ne bi radilo o pluralitetu osoba nego bi se radilo o pluralitetu kaznenih djela tj. o dvama autonomnim kaznenim djelima. ${ }^{20}$

Peto, pitanje trenutka u kojem je korupcijsko kazneno djelo dovršeno, razrješuje se dovođenjem u vezu s prethodno izloženim konceptom korupcijskog ugovora i radnje počinjenja kaznenog djela kako je propisana u člancima 318. i 319. CP-a. Iz toga proizlazi da se trenutak kada je korupcijsko kazneno djelo dovršeno određuje s obzirom na to je li izvršen korupcijski ugovor. Ako je taj ugovor izvršen, tada je korupcijsko kazneno djelo dovršeno u trenutku predaje odnosno primitka novca ili druge koristi. Ako taj ugovor nije izvršen, tada je korupcijsko kazneno djelo dovršeno u trenutku kada je taj ugovor sklopljen odnosno kada je prihvaćena ponuda za sklapanje tog ugovora. ${ }^{21}$

Šesta je opća karakteristika korupcijskih kaznenih djela ta što se zakonski opis tih djela ostvaruje u slobodnoj volji supočinitelja i uz izostanak prisile. Odatle i prethodno izloženi koncept korupcijskog ugovora sklopljenog slobodnom voljom suugovaratelja - supočinitelja korupcijskog delikta. Budući da prisila nije element bića korupcijskih kaznenih djela, kod prisilom postignute novčane ili druge koristi nikada se ne radi o korupcijskom kaznenom djelu nego se radi o kaznenom djelu konkuzije iz članka 317. CP-a koje može počiniti jedino službena osoba ili osoba kojoj je povjerena javna služba. ${ }^{22}$ Tako se i u sudskoj praksi obrazlaže da je „razlika između konkuzije i korupcije u tomu što se jedino kod potonje radi o slobodnoj volji privatnog subjekta, pa se stoga radi o konkuziji te privatni subjekt ne odgovara za aktivnu korupciju uvijek kada naknadu službenoj osobi nije dao u slobodnoj volji nego pod utjecajem djelovanja te službene osobe“ ${ }^{23} \mathrm{U}$ doktrini se ovo razlikovanje sažima u formulu prema kojoj korupciji nedostaje konkuzijski element prisile, a konkuziji nedostaje korupcijski element ugovora. ${ }^{24}$

19 V. (op. cit. bilj. 8), str. 139; Vinciguerra (op. cit. bilj. 4), str. 195-198, Ponti (op. cit. bilj. 11), str. 52; Antolisei (op. cit. bilj. 4), str. 344; Guerrini, Guidi (op. cit. bilj. 11), str. 107-108.

20 O tom (manjinskom) shvaćanju, njegovim argumentima i pristalicama vidi (op. cit. bilj. 3), str. 1623-1624.

$21 \quad$ Usp. (op. cit. bilj. 8), str. 190-191, Ponti (op. cit. bilj. 11), str. 5.

22 Antolisei (op. cit. bilj. 4), str. 347-349, Triolo (op. cit. bilj. 3), str. 114.

23 Tako u C., Sez. VI., 19. I. 1998., v. (op. cit. bilj. 2), str. 1632, 1656.

24 Tako Ferrante, Massimo Luigi: Le Fattispecie di corruzione, I delitti contro la Pubblica Amministrazione, aggiornamento alla 2. ed., Giuffrè Ed., 2010., str. 34. 
Mijo Galiot: Osnovne značajke kaznenopravne zaštite protiv korupcije u talijanskom zakonodavstvu... Zbornik radova Pravnog fakulteta u Splitu, god. 54, 2/2017., str. 503.- 531.

\subsubsection{Posebno o radnji (radnjama) počinjenja stožernih korupcijskih kaznenih djela}

Nastavno, dajemo pregled osnovnih shvaćanja doktrine i sudske prakse vezano za radnju počinjenja stožernih korupcijskih delikata iz članaka 318. i 319. CP-a.

Radnja počinjenja kaznenog djela neprave korupcije iz članka 318. CP-a u vezi s člankom 321. CP-a sastoji se u tomu da službena osoba, za izvršavanje svojih funkcija ili svojih ovlasti, od privatne osobe (koruptora), za sebe ili za treću osobu, neovlašteno primi novac ili drugu korist ili prihvati obećanje iste.

Prethodno izložena radnja počinjenja kaznenog djela neprave korupcije propisana je člankom 318. CP-a, u njegovoj trenutno važećoj verziji kako je propisana izmjenom CP-a iz 2012. godine.

Prije te izmjene, radnja počinjenja kaznenog djela neprave korupcije iz članka 318. stavak 1. CP-a u vezi sa člankom 321. CP-a sastojala se u tomu da službena osoba, za izvršenje radnje iz svoje službe, od privatne osobe (koruptora), primi, za sebe ili za treću osobu, u novcu ili drugoj koristi, retribuciju koja nije dugovana, ili prihvati obećanje iste, dok se radnja počinjenja, predviđena u stavku 2. tog članka, sastojala u tomu da službena osoba od privatne osobe (koruptora) primi retribuciju za službenu radnju koju je već izvršila.

Usporedi li se radnja počinjenja kaznenog djela iz sada i iz ranije važećeg članka 318. CP-a, razvidno je da sada više nije inkriminirana radnja koju je ranije inkriminirao stavak 2. tog članka. U tom se pravcu i u doktrini iznosi tumačenje da se prema važećem članku 318. CP-a, kako je noveliran izmjenom CP-a iz 2012., više ne kažnjava naknadna neprava pasivna korupcija, nego se kažnjava samo prethodna neprava pasivna korupcija. ${ }^{25}$ Neprava aktivna korupcija je, i prije ove novele, prema članku 321. CP-a bila kažnjiva jedino u prethodnom obliku. Tako je u vezi sa člankom 318., izmjena CP-a iz 2012. uspostavila jednaki kaznenopravni tretman aktivnog i pasivnog oblika neprave korupcije, i to na način da je sada propisano kažnjavanje jedino za prethodnu nepravu korupciju (i to kako za onu pasivnu, tako i za onu aktivnu), dok je napušteno ranije propisano kažnjavanje (samo) pasivne naknadne neprave korupcije. U tom se smislu i doktrinarna tumačenja pozivaju na to da je za naknadni oblik neprave pasivne korupcije ranije bila propisana blaža kazna nego za prethodni oblik iste, dok za aktivni pandan iste članka 321. nije ni propisivao kažnjavanje. No, ne treba zanemariti prisutnost tomu suprotnih doktrinarnih tumačenja koja smatraju da se zakonska sintagma o ,izvršavanju svojih funkcija ili svojih ovlasti“" ne bi odnosila samo na prethodnu, nego i na naknadnu, nepravu pasivnu korupciju. ${ }^{26}$

25 V. op. cit. bilj. 19 str. 23.

26 U tom smislu v. Andreazza, Gastone; Pistorelli, Luiggi: „Una prima lettura della legge 6. novembre 2012, n. 190 (Disposizioni per la prevenzione e la repressione della corruzione e dell' ilegalità nella pubblica amministrazione)“, Diritto penale contemporaneo, br. 3-4/2012, str. 4 i d.; Brunelli, David: „Le disposizioni penali nella legge contro la corruzione: un primo commento"; Rivista di diritto pubblico italiano, comparato, europeo, br. 23/2012, str. 6; Dolcini, Emilio; Vigano, Francesco: „Sulla riforma in cantiere dei delitti di corruzione (testo aggiornato alla luce dell'emendamento presentato dal governo)“, Diritto penale contemporaneo, br. 1/2012, str. 234 i d. 
Sama usporedba sada propisane radnje počinjenja kaznenog djela iz članka 318. $\mathrm{CP}-\mathrm{a}$ i one ranije propisane, upućuje na još dva zapažanja.

Prvotno, više se ne govori o „compiare un atto del suo ufficio“ (,izvršenju radnje iz svoje službe“) nego se sada govori o "l'esercizio delle sue funzioni o dei suoi poteri“ (,izvršavanju svojih funkcija ili svojih ovlasti“).

I nadalje izostavljeno je ranije izričito spominjanje retributivne svrhe novca ili druge koristi.

Tako se, vezano za sintagmu „l'esercizio delle sue funzioni o dei suoi poteri“ (,izvršavanje svojih funkcija ili svojih ovlasti“), u doktrini prigovara da je još više neodređena nego li ranije propisana sintagma , un atto del suo ufficio,, (,izvršenje radnje iz svoje službe"). Iznose se mišljenja da je ova izmjena inspirirana (prethodno već spomenutom) relativizacijom zahtjeva za određenošću ili odredivošću „radnje iz službe" u sudskoj praksi. Stoga se smatra da je ovakvom izmjenom u suštini legaliziran taj ranije stvoreni trend recentne sudske prakse. ${ }^{27}$

Što se tiče izostavljanja spomena retributivnosti, doktrinarna mišljenja idu u smjeru da to ne znači napuštanje koncepta dvostranoobvezujućeg koruptivnog ugovora, ali da bi moglo dovesti u pitanje koncept proporcionalnosti kojim se u praksi otklanjala kažnjivost za djelo iz članka 318. CP-a kod davanja darova manje vrijednosti. $^{28}$

Proizlazi da u prethodno izloženim dvjema novotama doktrinarna kritika nije prepoznala neku bitnije novu kvalitetu u odnosu na raniji sadržaj ove inkriminacije.

Ipak, doktrinarna tumačenja na višem stupnju uopćenosti, u navedenoj relativizaciji određenosti službeničke radnje i izostanku spomena retribucije, vide pomicanje fokusa sa kažnjavanja kupoprodaje službene radnje na kažnjavanje stavljanja službe odnosno funkcije na raspolaganje. ${ }^{29}$

Radnja počinjenja kaznenog djela prave korupcije iz članka 319. CP-a u vezi s člancima 320. i 321. CP-a sastoji se u tomu da službena osoba (ili osoba kojoj je povjerena javna služba); a da bi propustila ili odgodila, ili za propuštenu ili odgođenu radnju iz svoje službe; ili da bi izvršila, ili za izvršenu radnju protivnu obvezama službe; od privatne osobe (koruptora) primi, za sebe ili za treću osobu, novac ili drugu korist, ili prihvati obećanje iste.

Dakle, radnja službene osobe (ili osobe kojoj je povjerena javna služba) sastoji se od propuštanja ili odgađanja radnje iz službe ili izvršavanja radnje protivne obvezama službe, dok se radnja privatne osobe (koruptora) sastoji u obećavanju ili davanju novca ili druge koristi.

Za razliku od neprave korupcije, prava se korupcija, kako aktivna, tako i pasivna, kažnjava i u naknadnom i u prethodnom obliku.

\footnotetext{
27 V. op. cit. bilj. 19, str. 26.

28 V. op. cit. bilj. 19, str. 25.

29 V. op. cit. bilj. 19, str. 27-28.
} 


\subsubsection{Radnja iz svoje službe}

U daljnjem dijelu rada daje se prikaz glavnih shvaćanja doktrine i sudske prakse vezano za najvažnije pravne pojmove iz izloženih stožernih inkriminacija sadržanih u člancima 318. i 319. CP-a, a to su pojmovi: ,atto del ufficio“ (,radnje iz svoje službe“), ,atto contrario ai doveri di ufficio“ (,,radnja protivna obvezama službe“) $\mathrm{i}$,denaro o altra utilità“ (,novac ili druga korist“).

Tako u pogledu pojma ,atto del ufficio“ (,radnja iz svoje službe“) izdvajamo:

- $\quad$ shvaćanje sudske prakse (izrečeno u vezi s osudom za kazneno djelo iz članka 318. CP-a) da se radi o takvom postupanju službene osobe kod izvršene radnje iz službe (u konkretnom slučaju radilo se o donošenju rješenja u upravnom postupku), da se to postupanje, samo po sebi uzeto, u slučaju da je kod službene osobe izostalo primanje novčanog iznosa koji je za donošenje tog upravnog rješenja primila od strane privatne osobe, tu službenu osobu ne bi moglo podvrgnuti ni kaznenopravnom ni disciplinskom sankcioniranju; 30

- shvaćanje sudske prakse (također izrečeno u vezi s osudom za kazneno djelo iz članka 318. CP-a) da protupravnost nije sadržana u poduzimanju radnje iz službe nego u postupanju službene osobe u kojem se očitovalo njezino privatiziranje službe zbog čega je takvo ponašanje službene osobe protivno pravnoj obvezi nepristranog obavljanja službe u javnom interesu, pa je utoliko nedopušteno i nezakonito; ${ }^{31}$

- doktrinarno shvaćanje da se po pravnoj naravi radi o aktu koji je, uzet sam za sebe, zakonit, dopušten i poduzet od strane nadležnog tijela u izvršavanju njegove nadležnosti; ${ }^{32}$

- doktrinarno shvaćanje prema kojem se značenje kaznenopravnog pojma „atto del ufficio“ (,radnja iz svoje službe“) ne iscrpljuje samo u njegovu formalnom značenju nego se odnosi i na svako konkretno izvršavanje nekog ovlaštenja povezanog sa službom; ${ }^{33}$

- na tragu potonje navedenog doktrinarnog shvaćanja, i shvaćanje iz sudske prakse kako nije odlučno da se radi o radnji koja je u sferi onih specifičnih zadataka što ih baš ta službena osoba obavlja u službi, nego je nužno i dostatno da ta radnja spada u nadležnosti organa kojemu pripada službena osoba te da službena osoba u pogledu obavljanja te radnje ima ili može imati barem samo faktičku mogućnost utjecaja; ${ }^{34}$

- doktrinarni zahtjev određenosti ili barem odredivosti radnje iz

\footnotetext{
30 V. Carcano (op. cit. bilj. 3), str. 167, Cass., 25. IX. 2003.

31 V. Carcano (op. cit. bilj. 3), str. 167, Cass., 12. XI. 1998.

32 V. op. cit. (bilj. 2), str. 1642.

33 V. Carcano (op. cit. bilj. 3), str. 159.

34 V. Carcano (op. cit. bilj. 3), str. 162, Cass., 27. X. 2003.
} 
službe, koji se tumači kao odraz zahtjeva određenosti ili odredivosti stranačkih činidaba iz (korupcijskog) ugovora, ${ }^{35}$

- prihvaćanje prethodno navedenog doktrinarnog zahtjeva u starijoj i u recentnoj sudskoj praksi, s tim da je kod recentnije sudske praske primjetan trend ublažavanja i relativizacije tog zahtjeva, što je razvidno pođe li se od shvaćanja sudske prakse da se mora raditi o specifično individualiziranoj radnji (tako, primjerice, u C., Sez. VI., 24. XI. 1981.), preko shvaćanja sudske prakse da se mora raditi o radnji koja je barem odrediva (tako primjerice, u C., Sez. VI., 17. II. 1996.), do, najzad, shvaćanja u sudskoj praksi kako je dostatno (samo to) da je korist dana imajući u vidu službu koju službena osoba obavlja (tako, primjerice, u C., Sez. VI., 05. II. 1998.). ${ }^{36}$

\subsubsection{Radnja protivna obvezama službe}

Što se tiče izraza „,atto contrario ai doveri di ufficio“ (,,radnja protivna obvezama službe"):

- prema jednom tumačenju iz sudske prakse, značenje tog izraza ne iscrpljuje se samo u njegovoj formalnoj dimenziji nego obuhvaća svako ponašanje službene osobe koje je protivno pravnoj normi, pravilima službe ili na bilo koji način vrijeđa specifične obveze vjernosti službi, čestitosti i nepristranosti u obavljanju službe o kojima treba voditi računa svatko tko obavlja takvu javnu funkciju, pri čemu nije odlučno to što postoje nedostaci u in concreto individualizaciji same radnje $;^{37}$

- taj pojam, prema shvaćanju iz sudske prakse, ne obuhvaća samo one radnje koje su nezakonite ili nelegitimne nego i sve one radnje što ih je službena osoba poduzela u svjesnom zanemarivanju neke od specifičnih obveza koje službenoj osobi vezano za njezinu službu propisuje pravna norma bilo kojeg ranga; ${ }^{38}$

- da je pod taj pojam, prema doktrinarnom shvaćanju koje je prihvaćeno i u sudskoj praksi, podvediv i slučaj odlučivanja na temelju diskrecijskog ovlaštenja. Ovo jer je zakonom službenoj osobi dodijeljeno ovlaštenje diskrecijskog odlučivanja radi zaštite javnog interesa. Odluke se po diskrecijskom ovlaštenju i donose odvagivanjem najboljeg javnog interesa, dok su u slučaju korumpiranog diskrecijskog odlučivanja kod službene osobe prevagnuli njezina korist i privatni interes koruptora na uštrb zaštite javnog interesa radi kojega je diskrecijsko ovlaštenje službenoj osobi propisom i dodijeljeno. ${ }^{39}$

\footnotetext{
35 V. op. cit. (bilj. 8), str. 179 i 182; Fortuna, Mario: I delitti conto la Pubblica Amministarzione - I delitti dei pubblici ufficiali, Commentato sistematico, 3. ed. Giuffrè Ed., 2013. str. 185-186.

36 V. op. cit. (bilj. 2), str. 1643.

37 V. Carcano (op. cit. bilj. 3), str.. 159, Cass., 15. II. 1999.

38 V. Carcano (op. cit. bilj. 3), str. 160, Cass., 05. IX. 2003.

39 V. Carcano (op. cit. bilj. 3), str. 160; op. cit. (bilj. 2), str. 1642.
} 


\subsubsection{O mitu kao o novčanoj ili drugoj koristi}

Novac ili druga korist (,,denaro o altra utilită“) objekt je davanja odnosno obećanja privatne osobe (koruptora) službenoj osobi (ili osobi kojoj je povjerena javna služba) i tako se pojavljuje kao element bića djela kod svih oblika korupcijskih inkriminacija.

S tim u vezi, u doktrini i praksi se prijepornim pokazalo značenje „druge koristi“ (,altra utilită“). Starija doktrina, i relativno starija sudska praksa ${ }^{40}$ bile su sklone užem tumačenju o tzv. nužno patrimonijalnoj (imovinskoj) naravi druge koristi. Ova su doktrinarna shvaćanja potom potisnuta učenjima prema kojima nije odlučno da se radi o kakvom materijalnom dobru, nego je odlučno da se radi o prenosivom dobru. Daljnji su doktrinarni stavovi također išli u smjeru sve šireg tumačenja. Tako su pod pojam ,druge koristi“ podvela svaku vrstu zadovoljavanja bilo kakvih potreba ili interesa. Sudska je praksa pod taj pojam podvela i seksualne usluge. ${ }^{41} 42$

S prethodnim u vezi, pojavilo se pitanje darova i drugih koristi manje vrijednosti (tzv. „munuscula“). Stajalište po tom pitanju nije usuglašeno, ni u doktrini ni u sudskoj praksi.

Većina doktrinarnih pristupa, i u novije vrijeme, ovom pitanju pristupa u ključu proporcionalnosti. To je opet $u$ vezi s retributivnošću odnosno s navedenim konceptom korupcijskog ugovora. Retributivnost primljenog novaca ili druge koristi izričito se navodila samo u odredbi iz članka 318., i to prije izmjene te odredbe iz 2012. kojom je brisan spomen retributivnosti u toj odredbi, dok se u odredbi iz članka 319. nije ni navodila. Unatoč tomu, i praksa i doktrina, ostajući dosljedne zasnivanju cijelog koncepta korupcijskih inkriminacija na navedenoj figuri korupcijskog dvostranoobveznog ugovora, princip retributivnosti (i tome posljedični princip proporcionalnosti između radnje i koristi) nisu samo vezale za nepravu korupciju iz članka 318. CP-a nego su ga proširivale i na pravu korupciju iz članka 319. CP-a.

Većinska su doktrinarna stajališta branila nekažnjavanje darova i koristi manje vrijednosti, smatrajući da takvom svojom vrijednošću nisu u proporciji s mogućnošću ugroze službeničkog ponašanja pa da tako službeničko ponašanje kod tih i takvih darova ostaje intaktno (netaknuto).

Iako se i u sudskoj praksi obrazlaže na tom tragu, ipak se pitanje je li vrijednost dara kaznenopravno relevantna u smislu korupcijskih inkriminacija razrješava uzimanjem u obzir okolnosti konkretnog slučaja. Primjetno je da se sudska praksa, po ovom pitanju, za princip proporcionalnosti više drži kod neprave i kod naknadne korupcije jer je kod tih oblika korupcije lakše braniti intaktnost službeničkog ponašanja. No, kod prave i prethodne korupcije, sudska praksa ne odriče apriorno korupcijski značaj darova manje vrijednosti nego ga ocjenjuje prema okolnostima

40 C., Sez. III., 03. V. 1991.

41 C., Sez. un., 11. V. 1993.

42 Usp. Antolisei (op. cit. bilj. 4), str. 356, op. cit. (bilj. 2), str. 1638-1639. 
konkretnog slučaja. ${ }^{43}$ Ima doktrinarnih shvaćanja da pretjerano inzistiranje na retributivnom (proporcijskom) elementu dovodi u opasnost cijeli koncept kaznenopravne zaštite protiv korupcije utoliko što, ulaženjem u pitanje vrijednosti primljene koristi, potiskuje primarnu postavku zaštite od svih oblika privatizacije javne službe ${ }^{44} \mathrm{Na}$ tom je tragu i posljednja novela članka 318 . CP-a kojom je izostavljen spomen retributivnosti, odnosno doktrinarna shvaćanja iznesena u vezi $\mathrm{s}$ tom novelom koja smo prethodno već i spomenuli. ${ }^{45}$

\subsubsection{Posebni dio tzv. minisustava korupcijskih kaznenih djela}

Poseban dio promatranog minisustava tiče se korupcije u sudskim radnjama (članak 319-ter CP-a), pokušaja i poticanja kod korupcije (članak 322. CP-a), te korupcije s međunarodnim i nadnacionalnim elementom (članak 322-bis CP-a).

\subsubsection{Korupcija u sudskim radnjama}

Članak 319-ter CP-a nosi naslov „Korupcija u sudskim radnjama“, te u stavku 1. propisuje da se, u slučaju kada je zakonski opis iz članka 318. i 319. ostvaren da bi se pogodovalo ili oštetilo stranku građanskog ili kaznenog postupka ili upravnog spora, primjenjuje kazna zatvora od šest do dvanaest godina. U stavku 2. propisuje da ako iz toga proiziđe nečija nezakonita osuda na kaznu zatvora u trajanju ne duljem od 5 godina, tada je kazna zatvora od pet do četrnaest godina, a za slučaj nezakonite osude na kaznu zatvora u trajanju duljem od pet godina ili na kaznu doživotnog zatvora, propisana je kazna zatvora u trajanju od osam do dvadeset godina.

Izloženi trenutno važeći zakonski opis ove inkriminacije uveden je u talijansko pravo izmjenom CP-a iz 1990. i otada nije mijenjan, dok su se izmjene CP-a iz 2012. i 2015. odnosile jedino na ovim člankom propisanu mjeru kaznenopravne sankcije odnosno kazne zatvora.

U pogledu ove inkriminacije, dajemo pregled najvažnijih, te u doktrini i sudskoj praksi usuglašenih shvaćanja, kako slijedi: ${ }^{46}$

- dobra koja se štite ovom inkriminacijom jesu transparentnost i moralni autoritet u sudskom postupanju i odlučivanju;

- ne radi se o kvalificiranom obliku kaznenih djela iz članka 318. i 319. $\mathrm{CP}-\mathrm{a}$, nego se radi o autonomnom kaznenom djelu koje je u odnosu specijalnosti spram kaznenih djela iz članka 318. i 319. CP-a (tako, primjerice, u C., Sez. VI, 16. XI. 2001.), pri čemu se specijalizirajuća okolnost iz zakonskog opisa ovog kaznenog djela, u odnosu na

43 Usp. op. cit. (bilj. 2), str. 1647-1650; Carcano (op. cit. bilj. 3), str. 167.

44 Usp. (op. cit. bilj. 8), str. 149-151.

45 V. bilj. 24.

46 Usp. op. cit. (bilj. 2), str. 1663-1669. 
zakonske opise kaznenih djela iz članka 318. i 319. CP-a, očituje u svrsi pogodovanja ili oštećenja stranke sudskog procesa koja je svojstvena ovom kaznenom djelu; 47

- kazneno djelo iz stavka 2. ovog članka kvalificirani je oblik kaznenog djela iz stavka 1. ovog članka (tako, primjerice, u C., Sez. III, 06. X. 1995.);

- budući da je po svojoj prirodi sudska funkcija državna vlast, a nije javna služba, to u krug počinitelja ovog kaznenog djela spada samo službena osoba iz članka 357. CP-a, a ne i osoba kojoj je povjereno obavljanje javne službe iz članka 358. CP-a;

- postojanje svrhe pogodovanja ili oštećenja stranke sudskog procesa iz zakonskog opisa ovog kaznenog djela ne procjenjuje samo s obzirom na način kako je proces pravomoćno završen nego s obzirom na sve stadije i sve procesne radnje tog procesa;

- značenje sudskog procesa i njegove stranke uzima se u pravnotehničkom smislu koji propisuje odgovarajuće procesno zakonodavstvo o građanskim postupcima te o kaznenom postupku i upravnom sporu, s time da se u kaznenim stvarima uzima i šire pa obuhvaća i osobu pod istragom (tako, primjerice, u C., Sez. VI, 16. XI. 2001.).

\subsubsection{Poticanje na aktivno podmićivanje}

Što se tiče članka 322. CP-a, taj je članak naslovljen „Poticanje na korupciju“, a njegovim je odredbama propisano:

- u stavku 1.: tko ponudi ili obeća novac ili drugu korist službenoj osobi ili osobi kojoj je povjerena javna služba, za izvršavanje njezinih funkcija ili njezinih ovlasti, podliježe, ako ta ponuda ili obećanje nije prihvaćeno, kazni, propisanoj u članku 318. stavak 1., ublaženoj za jednu trećinu;

- u stavku 2.: ako je ponuda ili obećanje učinjeno radi poticanja službene osobe ili osobe kojoj je povjerena javna služba da propusti ili odgodi radnju iz svoje službe ili da izvrši radnju protivnu obvezama službe, počinitelj podliježe, ako ta ponuda ili obećanje nije prihvaćeno, kazni, propisanoj u članku 319., ublaženoj za jednu trećinu;

- u stavku 3.: kazni iz stavka 1. ovog članka podliježe službena osoba ili osoba kojoj je povjerena javna služba koja potakne na obećavanje ili davanje novca ili druge koristi za izvršavanje svojih funkcija ili svojih ovlasti;

- u stavku 4.: kazni iz stavka 2. ovog članka podliježe službena osoba ili osoba kojoj je povjerena javna služba koja potakne na obećavanje ili davanje novca ili druge koristi od strane privatne osobe u svrhe propisane u članku 319.

47 Tako op. cit. (bilj. 4), str. 223, pozivom na izloženu mjerodavnu doktrinu i sudsku praksu. 
U pogledu prethodno izloženih odredaba članka 322. CP-a, sistematiziramo važnija shvaćanja doktrine i sudske prakse, kako slijedi: ${ }^{48}$

- U doktrini se kritizira naslov ovog članka. Ta kritika ide u pravcu da se odredbama iz ovog članka, po prvimaa u cijelosti, a po drugima u dijelu, ne propisuje kažnjavanje za poticanje nego se propisuje kažnjavanje za pokušaj. Tako ovi prvi kritičari, u cjelini sadržaja odredaba iz ovog članka, uopće ne vide kažnjavanje poticanja, nego vide kažnjavanje pokušaja aktivne, pasivne, prave i neprave korupcije. ${ }^{49}$ Ovi drugi, pak, u stavcima 1. i 2. ovog članka čitaju kažnjavanje za pokušaj neprave (stavak 1.) i prave (stavak 2.) korupcije, dok u stavcima 3. i 4. ovog članka čitaju kažnjavanje za poticanje na nepravu (stavak 3.) i pravu (stavak 4.) korupciju. ${ }^{50}$

- Većinsko je doktrinarno shvaćanje, koje je prihvaćeno u sudskoj praksi, da odredbe ovog članka, kao specijalne i autonomne odredbe, isključuje primjenu odredaba općeg dijela CP-a o kažnjavanju pokušaja kaznenog djela (članak 56. CP-a) i o kažnjavanju poticanja (članka 115. CP-a) u vezi s odredbama iz članaka 318. i 319. te 321. CP-a. Prema ovom shvaćanju, odredbe ovog članka propisuju kažnjavanje pokušaja (i poticanja) za kaznena djela iz članaka 318. i 319. te 321. CP-a u vezi s kojima stoga nema mjesta primjeni navedenih odredaba općeg dijela CP-a o kažnjavanju pokušaja i poticanja. Postoje i drukčija doktrinarna shvaćanja koja, dovođenjem u vezu odredaba iz članka 318. i 319. te 321. CP-a s odredbama općeg dijela CP-a o kažnjavanju pokušaja kaznenog djela (članak 56. CP-a), iščitavaju mogućnost kažnjavanja za pokušaj i u drugim solucijama od onih pokrivenih u članku 322. CP-a.

- Primjetno je da u odredbama članka 322. CP-a nema spomena članka 319-ter CP-a. U vezi s time, jedan dio doktrine je mišljenja da se odredbe iz članka 322. ipak implicitno odnose i na članak 319-ter CP-a koji izrijekom ne spominju, dok je drugi dio doktrine mišljenja da se stoga pokušaj kaznenog djela iz članka 319-ter CP-a kažnjava u primjeni odredbe općeg dijela CP-a o pokušaju (članak 56. CP-a), kojem mišljenju ovog drugog dijela doktrine se priklonila i sudska praksa (tako, primjerice, u C., Sez. VI., 06. II. 2007., n. 12409). ${ }^{51}$

48 Usp. (op. cit. bilj. 8), str. 234 i d., op. cit. (bilj. 2), str. 1681. i d.

49 Tako op. cit. (bilj. 2) str. 1682.

50 Tako Ponti (op. cit. bilj. 11), str. 59-60.

51 V. op. cit. (bilj. 2), str. 1668. 


\subsubsection{Međunarodni aspekt}

Članak 322-bis CP-a, u relevantnom dijelu koji se odnosi na korupciju i poticanje na korupciju članova Međunarodnog kaznenog suda ili organa Europske unije ili službenika Europske unije i stranih država, propisuje:

- u stavku 1.: da se odredbe iz članaka 318. do 320. i članka 322. stavaka 3. i 4. primjenjuju i na: 1) članove Europske komisije, Europskog parlamenta, Europskog suda pravde i Revizorskog suda Europske unije; 2) službenike i agente zaposlene po osnovi ugovora utemeljenog na poslovničkim ili radnopravnim pravilima Europske unije; 3) osobe pod mandatom država članica ili bilo kojeg javnog ili privatnog tijela pri Europskoj uniji, koje obavljaju funkcije odgovarajuće onima što ih obavljaju službenici i agenti Europske unije; 4) članove i zaposlenike tijela osnovanih na temelju osnivačkih ugovora Europske unije; 5) na one koji, u drugim državama članicama Europske unije, obavljaju funkcije ili aktivnosti odgovarajuće onima što ih obavljaju službene osobe i osobe kojima je povjerena javna služba; 5-bis) na suce, tužitelje, dodatne tužitelje, službenike i agente Međunarodnog kaznenog suda, osobe pod mandatom država ugovornica Ugovora o osnivanju Međunarodnog kaznenog suda koje obavljaju funkcije odgovarajuće onima što ih obavljaju službenici i agenti toga suda, kao i na članove i zaposlenike tijela osnovanih na temelju Ugovora o osnivanju Međunarodnog kaznenog suda;

- u stavku 2: da se odredbe iz članaka 321.i322. stavak 1.i 2. primjenjuju i ako se novac ili druga korist dade, ponudi ili obeća: 1) osobama navedenima u stavku 1. ovoga članka; 2) osobama koje obavljaju funkcije ili aktivnosti odgovarajuće onima što ih obavljaju službene osobe i osobe kojima je povjerena javna služba u stranim državama ili međunarodnim organizacijama, kadgod je to kazneno djelo počinjeno da bi se sebi ili drugome osiguralo nepripadnu dobit u međunarodnom poslovanju ili kako bi se steklo ili zadržalo ekonomsku ili financijsku aktivnost;

- u stavku 3: da se osobe navedene u stavku 1. smatraju službenim osobama kadgod obavljaju odgovarajuće funkcije, dok se u drugim slučajevima smatraju osobama kojima je povjerena javna služba.

Općenito govoreći, prethodno izložene iscrpne odredbe iz članka 322-bis CPa, promatrane u cjelini svojega sadržaja u pogledu u relevantnom dijelu koji se odnosi na korupciju i poticanje na korupciju članova Međunarodnog kaznenog suda ili organa Europske unije ili službenika Europske unije i stranih država imaju kaznenopravno značenje propisivanja korupcijskih kaznenih djela $\mathrm{s}$ međunarodnim i nadnacionalnim elementom, te propisivanja uvjeta pod kojima korupcijske inkriminacije iz talijanskog nacionalnog kaznenog zakonodavstva imaju ekstrateritorijalni učinak. 
Nakon što smo ovim zaokružili prikaz iz tzv. posebnog dijela minisustava korupcijskih kaznenih djela, ukazat ćemo još i na jednu odredbu koja ne pripadna tom sustavu, nego je pripadna posebnom talijanskom kaznenom zakonodavstvu.

Radi se o članku 2635. talijanskog Građanskog zakonika (Codice Civile; u daljnjem tekstu: CP) ${ }^{52}$ koji nosi naslov „Korupcija među privatnim osobama“..$^{53}$

U stavku 1. tog članka propisano je da će se, za slučaj da nije počinjeno neko teže kazneno djelo, članovi uprave, generalni direktori, menadžeri odgovorni za računovodstvenu dokumentaciju trgovačkog društva, revizori i likvidatori koji, slijedom danog ili obećanog novca ili druge koristi, za sebe ili za drugoga, izvrše ili propuste radnje, povređujući time obveze iz svoje službe ili iz odnosa povjerenja kazniti kaznom zatvora od jedne do tri godine.

Stavak 2. tog članka propisuje da se primjenjuje kazna zatvora do jedne godine i šest mjeseci ako je djelo počinjeno od strane osobe koja je podložena naredbama i nadzoru neke od osoba navedenih u stavku 1.

Stavkom 3. tog članka propisano je da se onaj tko dade ili obeća novac ili drugu korist osobama navedenima u stavcima 1. i 2. kažnjava kaznama propisanima u tim stavcima.

Prema stavku 4. toga članka, kazne propisane prethodnim stavcima udvostručuju se ako se radi o trgovačkom društvu čije se dionice izlistavaju na burzi u Italiji ili drugoj članici Europske unije ili javno distribuiraju u mjeri koja je relevantna u smislu članka 116. konsolidiranih pravila u oblasti financijskog posredovanja, a sukladno Dekret-zakonu broj 58. od 24. veljače 1998., s izmjenama i dopunama.

Stavkom 5. ovoga članka propisan je kazneni progon po privatnoj tužbi, osim u slučaju kada proizlazi da je povrijeđena sloboda natjecanja na tržištu dobara ili usluga.

\subsubsection{Zakonska politika kažnjavanja davatelja mita}

U promatranom dijelu analiziraju se odredbe zakonske politike kažnjavanja korupcijskih kaznenih djela, navođenjem propisane mjere zapriječene kaznenopravne sankcije (kazne zatvora) po pojedinim korupcijskim inkriminacijama, uz istovremeno prikazivanje recentnijih zakonodavnih izmjena s tim u vezi, a sve kako bismo tako oslikali pravac vremenskog kretanja talijanske zakonske politike kažnjavanja ovih kaznenih djela. ${ }^{54}$

Prvo, za kazneno djelo tzv. neprave korupcije iz članka 318. CP-a, zapriječena je kazna zatvora u trajanju od jedne do šest godina, a kako je to propisano izmjenom CP-a iz 2015. Prije izmjene CP-a iz 2015., bila je propisana kazna zatvora u trajanju

52 Codice civile, (trenutno važeći) talijanski Kazneni zakonik, koji je u definitivnom tekstu objavljen u izvanrednom izdanju Službenog glasila (Gazzeta Ufficiale) broj 79 od 4. travnja 1942., zajedno sa svim kasnijim izmjenama i dopunama (u daljnjem tekstu: CC).

53 Usp. (op. cit. bilj. 14) str. 111-112.

54 Usp. (op. cit. bilj. 24), str. 22, 29, 30, 32. 
od jedne do pet godina, prema izmjeni CP-a iz 2012. Prethodno tomu, a prema izmjeni CP-a iz 1990., stavak 1. ovog članka propisivao je kazneno djelo prethodne neprave korupcije i kaznu zatvora za isto u trajanju od šest mjeseci do tri godine, a stavak 2. ovog članka propisivao je kazneno djelo naknadne neprave korupcije i kaznu zatvora za isto u trajanju do jedne godine.

Drugo, za kazneno djelo prave korupcije u članka 319. CP-a propisana je kazna zatvora u trajanju od šest do deset godina, kako je propisano izmjenom CP-a iz 2015. Prije toga je, prema izmjeni CP-a iz 2012., bila propisana kazna zatvora u trajanju od četiri do osam godina, dok je u verziji ovog članka, prema izmjeni CP-a iz 1990., bila propisana kazna zatvora u trajanju od dvije do pet godina.

Treće, kod kaznenog djela korupcije u sudskim radnjama iz članka 319-ter CP-a propisana je, za temeljni oblik iz stavka 1., kazna zatvora u trajanju od šest do dvanaest godina, dok je za kvalificirani oblik iz stavka drugog propisana kazna zatvora u trajanju od šest do četrnaest godina (za blaže kvalificirani oblik) odnosno od osam do dvadeset godina (za teže kvalificirani oblik). Ovakvo je sankcioniranje propisano izmjenom iz 2015. Prije toga, a prema izmjeni iz 2012., za temeljni oblik iz stavka 1. bila je zapriječena kazna zatvora u trajanju od četiri do deset godina, dok je za kvalificirani oblik iz stavka 2. bila zapriječena kazna zatvora u trajanju od pet do dvanaest godina (za blaže kvalificirani oblik) odnosno od šest do dvadeset godina (za teže kvalificirani oblik).

Četvrto, kod kaznenog djela privatne korupcije iz članka 2635. CC, nije bilo recentnijih izmjena zapriječene mjere kazne zatvora koja je za temeljni oblik tog kaznenog djela propisana u trajanju od jedne do tri godine, dok je za kvalificirani oblik propisano njezino udvostručenje.

Peto, članak 320. stavak 2. CP-a propisuje da se kod kažnjavanja osoba kojima je povjerena javna služba za kaznena djela iz članaka 318. i 319. u svakom slučaju kazne ublažavaju u mjeri ne većoj od jedne trećine.

Kod ovakvog se okvira zakonske politike kažnjavanja prvenstveno nameće zaključak da se talijanski sustav zakonske politike kažnjavanja, kod korupcijskih inkriminacija, temelji na odabiru kazne zatvore kao vrste zapriječene kaznenopravne sankcije, pri čemu je, u pogledu propisivanje te vrste kaznenopravne sankcije, baš kao i u pogledu zakonskog propisivanja njezine mjere, dosljedno primijenjen model simetričnih kaznenopravnih sankcija koji karakterizira zakonska zapriječenost iste vrste i mjere kaznenopravne sankcije i za aktivnu i za pasivnu korupciju, a uz to je i propisano blaže kažnjavanje za korupciju u javnoj službi. ${ }^{55}$

Nadalje, usporedba navedenih recentnijih (2012. i 2015.) zakonodavnih izmjena koje su se ticale zapriječene mjere kaznene zatvora, ukazuje na nedvojbeno postojanje evidentnog trenda, i to ne malog, povećavanja zapriječene mjere kazne zatvora za korupcijska kaznena djela. To daje uporište zaključku da se u talijanskom društvu,

55 V. Yu, Geoneng, Yu, Geoneng: „Towards More Reasonable and Effective Punishment Strategies for Bribery“, A Comparative and Behavioral Study, Verlag Dr. Kovač, Hamburg, 2012., str. 47 i 48. 
korupcijski kriminal, i u aktualnom trenutku, i dalje prepoznaje kao prisutna i velika društvena opasnost.

Vezano za sudsku politiku kažnjavanja, posebnom su zakonskom odredbom izričito propisane one okolnosti koje se mora uzeti u obzir kao otegotne prilikom sudskog odmjeravanja kazne za djelo iz članka 319. CP-a. Te su okolnosti: počinjenje tog djela u vezi s dodjelom dužnosti ili službe u javnoj upravi, s plaćom, mirovinom, ili sklapanjem ugovora koji se odnosi na tijelo kojem pripada službena osoba koja je počinila to kazneno djelo. ${ }^{56}$

Isto tako, posebnom zakonskom odredbom propisane su i sljedeće izričite zakonske ovlasti ublažavanja kazne: (1) za djela iz članka 318., 319., 320., 322. i 322-bis zbog postojanja naročito olakotnih okolnosti; (2) kod kaznenih djela iz članka 318, 319, 319-ter, 320, 321, 322 i 322-bis ublažavanje kazne od jedne trećine do dvije trećine počiniteljima koji su učinkovito surađivali radi sprečavanja daljnje teže posljedice kaznenog djela, osiguranja dokaza i utvrđivanja počinitelja, ili oduzimanja danog novca ili druge koristi. ${ }^{57}$

Najzad, a vezano za sankcioniranje aktivne korupcije, u CP-u su sadržana još i pravila o:

- obligatornom donošenju odluke o oduzimanju imovinske koristi protupravno stečene korupcijskim kaznenim djelom, kao sastavnog dijela izreke osuđujuće presude za to kazneno djelo; ${ }^{58}$

- posebnom pravnom učinku osude za korupcijska kaznena djela u vidu zabrane ugovaranja s tijelima državnih i javnih službi. ${ }^{59} 60$

56 V. članak 319-bis CP-a

57 V. članak 323-bis CP-a

58 V. članak 322-ter CP-a

59 V. članci 32-ter i 32-quater CP-a.

60 Slično se, uzgred rečeno, sankcioniranja pasivne korupcije tiču i odredbe:

1) članaka 165. i 322-quater CP-a koje uređuju obligatorno donošenje odluke kojom se, neovisno o obvezi naknade štete, nalaže da se iznos u visini nepripadno primljenog novca ili koristi uplati u korist uprave odnosno javne službe kojoj službena osoba odnosno osoba koja obavlja javnu službu pripada, odnosno u korist pravosudne uprave kada se radi o kaznenom djelu iz članka 319-ter, a koja odluka se pojavljuje kao sastavni dio izreke presude kojom se za korupcijsko kazneno djelo izriče kazna bezuvjetnog zatvora, kao i izreke presude kojom se za to djelo primjenjuje uvjetna osuda, u kojem potonjem slučaju se radi o posebnoj obvezi uz uvjetnu osudu;

2) članka 317-bis CP-a koje uređuju obligatorno izricanje zabrana obavljanja javne dužnosti ili službe, kao sporedne kazne kod osude zbog kaznenog djela iz članka 319. i 319-ter CP-a, koja se u pravilu izriče trajno, a iznimno se izriče privremeno samo onda kada je uslijed postojanja naročito izraženih olakotnih okolnosti izrečena osuda na kaznu zatvora u trajanju kraćem od tri godine;

3) članka 32-quinquies CP-a prema kojima je učinak osude na kaznu zatvora u trajanju ne manjem od dvije godine za kaznena djela iz članaka 318., 319., 319-ter, i 320, prestanak radnog odnosa kod državnog ili javnog tijela ili pravne osobe s većinskim javnim udjelom. 


\section{ZAKLJUČAK - POREDBENA ANALIZA}

Završno, iznosimo temeljne usporedne sličnosti i razlike između sustava kaznenopravne zaštite protiv aktivne korupcije (podmićivanja) u talijanskom (CP) i hrvatskom (KZ) pravu, u pogledu propisanih oblika kaznenih djela, počinitelja, radnje počinjenja te propisane vrste i mjere kaznenopravne sankcije.

Što se tiče propisanih oblika kaznenog djela aktivne korupcije (podmićivanja), sličnost se ogleda u tomu što i KZ (u članku 294. stavak 1.) i CP (u članku 319. u vezi sa člankom 321) propisuju kažnjavanje pravog prethodnog aktivnog podmićivanja (korupcije). Sličnost je i u tom što i KZ (u članku 294. stavak 2.) i CP (u članku 318. u vezi sa člankom 321.) propisuju kažnjavanje nepravog prethodnog aktivnog podmićivanja (korupcije). Međutim, za razliku od KZ-a koji ne kažnjava naknadno aktivno podmićivanje, ni u pravom ni u nepravom obliku, CP (u članku 319. u vezi sa člankom 321.) propisuje kažnjavanje pravog oblika naknadne aktivne korupcije.

S tim u vezi, uočljive su razlike između CP-a i KZ-a i u pogledu poimanja prave i neprave korupcije (podmićivanja). Kod prave korupcije, $\mathrm{CP}$, u članku 319., s propuštanjem službene radnje izričito izjednačava i njezino odgađanje, dok KZ, u člancima 293. stavak 1. i 294. stavak 1., s neobavljanjem službene ili druge radnje koju bi se trebalo obaviti ne izjednačava, barem izričito, i njezino odgađanje. Kod neprave korupcije, za razliku od CP-a koji u članku 318. ima u vidu samo podmićivanje službene osobe za izvršavanje njezinih funkcija ili ovlasti, KZ kod nepravog podmićivanja, iz članaka 293. stavak 2. i 294. stavak 2., pored obavljanja službene ili druge radnje koju bi se moralo obaviti, ima u vidu još i neobavljanje službene ili druge radnje koju se ne bi smjelo obaviti, iz čega bi proizlazilo da pojam neprave korupcije po KZ-u sadrži više neprava od tog pojma po CP-u.

Nadalje, a za razliku od CP-a, u KZ-u (članak 294. stavak 1. i 2.) izričito je propisano da se posredovanje kod aktivnog podmićivanja kažnjava jednako kao i aktivno podmićivanje, čime se to posredovanje (koje je u biti pomaganje) ne tretira kao sudioništvo nego se tretira kao samostalno kazneno djelo. ${ }^{61}$

Imajući u vidu prethodno izloženu zakonsku regulativu te doktrinarna shvaćanja i sudsku praksu vezano za pojam ,i pubblici ufficiali“ (,službene osobe“) iz članka 357. CP-a i pojam ,persone incaricate di un pubblico servizio“ („osobe kojima je povjerena javna služba") iz članka 358. CP-a, a sve u vezi sa zakonskim opisima kaznenih djela (aktivne) korupcije iz članaka 318., 319. i 321. CP-a, razliku uočavamo i u tomu što prethodno navedeni pojmovi svakako obuhvaćaju širi krug osoba od onog obuhvaćenog pojmovima službene ili odgovorne osobe u smislu članka 87. stavci 3. i 6. KZ-a u vezi sa člankom 294. stvak 1. i 2. KZ-a.

Bitnu razliku vidimo i u tomu što, prema uvriježenim shvaćanjima hrvatske kaznenopravne doktrine i sudske prakse, (opće) kazneno djelo davanja mita iz članka 294. KZ-a i (posebno) kazneno djelo primanja mita iz članka 293. KZ-a dva su autonomna kaznena djela. Iako je i hrvatska doktrina na stajalištu da se

61 Tako op. cit. bilj. 61, str. 413. 
kod davanja i primanja mita radi o tzv. bilateralnom deliktu (deliktu susretanja), ${ }^{62}$ hrvatskoj doktrini i sudskoj praksi strana je figura jednog posebnog i bilateralnog kaznenog djela s nužnim sudioništvom supočiniteljskog tipa, koju prihvaćaju talijanska sudska praksa i većinska doktrina.

Što se pak tiče osobe počinitelja kod aktivne korupcije (podmićivanja), tu ne vidimo ikakve razlike između CP-a i KZ-a. Ovo jer se, i kao koruptor (privatna osoba, extraneus) u smislu članka 321. CP-a, i kao počinitelj (općeg) kaznenog djela davanja mita iz članka 294. KZ-a, može pojaviti svatko. S tim u vezi, uočavamo jedino već ranije istaknutu proturječnost u koju upada talijanska figura jednog posebnog i bilateralnog kaznenog djela s nužnim sudioništvom supočiniteljskog tipa kada istovremeno „čuva“ narav korupcijskog kaznenog djela kao posebnog kaznenog djela (delictum proprium) i na rang supočinitelja stavlja koruptora koji nema propisano svojstvo (službene osobe ili osobe kojoj je povjerena javna služba).

Isto tako, nema bitne razlike ni glede radnje počinjenja aktivne korupcije (podmićivanja), koju CP (u člancima 318. i 319) opisuje kao obećavanje ili davanje novca ili druge koristi, a KZ (u članku 294. u vezi sa člankom 87. stavak 24.) kao nuđenje, obećavanje ili davanje mita, a pojam mita zakonski se definira kao svaka nepripadna nagrada, dar ili druga imovinska ili neimovinska korist bez obzira na vrijednost.

Usporedbom zapriječenih kaznenopravnih sankcija, sličnost se ogleda u njihovoj istoj vrsti (kazna zatvora), a razlika u tomu što KZ nije, kao što je to slučaj u CP$\mathrm{u}$, primijenio sustav simetrične mjere sankcije za aktivnu i pasivnu korupciju (podmićivanje). Tako KZ veću mjeru kazne zatvora zaprečuje za kazneno djela primanja mita iz članka 293. KZ-a (od jedne do deset godina za pravi oblik iz stavka 1., te od jedne do osam godina za nepravi oblik iz stavka 2.) nego za kazneno djelo davanja mita iz članka 294. KZ-a (od jedne do osam godina za pravi oblik iz stavka 1., te od šest mjeseci do pet godina za nepravi oblik iz stavka 2.).

Usporedbe radi, za pravu (prethodnu i naknadu) aktivnu korupciju, u članku 319. u vezi sa člankom 321. CP-a, zapriječena je kazna zatvora od šest do deset godina, dok je za nepravu prethodnu aktivnu korupciju, u članku 318. u vezi sa člankom 321. CP-a, zapriječena kazna zatvora od jedne do šest godina. Iz toga proizlazi da, za sve usporedive oblike aktivne korupcije, $\mathrm{CP}$ zaprečuje veću mjeru kazne zatvora od KZ-a.

62 V. Novoselec, Petar (ur.): Posebni dio kaznenog prava, I. izd., Zagreb, 2007., str. 410-411. 


\section{LITERATURA}

- monografije:

Antolisei, Francesco: Manuale di Diritto Penale - Parte Speciale II, 15. ed. Giuffrè Ed., 2008.

Carcano, Domenico: Manuale di Diritto Penale - Parte Speciale, Giuffrè Ed., 2010.

Fortuna, Mario: I delitti conto la Pubblica Amministarzione - I delitti dei pubblici ufficiali, Commentato sistematico, 3. ed. Giuffrè Ed., 2013.

Lattanzi, Giorgio; Lupo, Ernesto: Codice Penale - Rassegna di giurisprudenza e di dottrina, Vol. VII., Libro II, Giuffrè Ed., 2010.

Ponti, Alberto: I principali delitti contro la Pubblica Amministrazione, HALLEY, 2002.

Primo Triolo, Dario: I reati contro la pubblica amministrazione, KEY SRL, 2015.

Ronco, Mauro; Romano, Bartolomeo: Codice Penale Commentato, IV. ed., UTET, 2012.

Vinciguerra, Sergio: I delitti contro la pubblica amministrazione, CEDAM, 2008.

- članci:

Andreazza, Gastone; Pistorelli, Luiggi: „Una prima lettura della legge 6. novembre 2012, n. 190 (Disposizioni per la prevenzione e la repressione della corruzione e dell' ilegalità nella pubblica amministrazione)“, Diritto penale contemporaneo, br. 3-4/2012, str. 1-21.

Brunelli, David: „Le disposizioni penali nella legge contro la corruzione: un primo commento"; Rivista di diritto pubblico italiano, comparato, europeo, br. 23/2012, str. 1-24.

Dolcini, Emilio; Vigano, Francesco: „Sulla riforma in cantiere dei delitti di corruzione (testo aggiornato alla luce dell'emendamento presentato dal governo)“, Diritto penale contemporaneo, br. 1/2012.

Ferrante, Massimo Luigi: Le Fattispecie di corruzione, I delitti contro la Pubblica Amministrazione, aggiornamento alla 2. ed., Giuffrè Ed., 2010., str. 19-35.

Guerrini, Roberto; Guidi, Dario: „Bribery in Italy - an outlook on present laws and perspectives on reform"; Modredn Bribery Law - Comparative perspectives, Cambridge University Press 2013., str. 97-127. 
- propisi:

Costituzione della Repubblica Italiana, Službeno glasilo (Gazzeta Ufficiale), broj 298 od 27. prosinca 1947., sa svim kasnijim izmjenama i dopunama.

Codice penale, Službeno glasilo (Gazzeta Ufficiale) Kraljevine Italije, broj 251 od 26. listopada 1930., sa svim kasnijim izmjenama i dopunama.

Codice civile, Službeno glasilo (Gazzeta Ufficiale), broj 79 od 4. travnja 1942., zajedno sa svim kasnijim izmjenama i dopunama.

Zakon broj 86. od 26. travnja 1990.

Zakon broj 190 od 6. studenog 2012.

Zakon broj 69 od 27. ožujka 2015.

- sudske odluke:

Cass., 22. II. 1991.

Cass., 22. XI. 1996.

Cass., 13. VII. 1998.

Cass., 12. XI. 1998.

Cass., 15. II. 1999.

Cass., 21. III. 2003.

Cass., 05. IX. 2003.

Cass., 25. IX. 2003.

Cass., 27. X. 2003.

Cass., 02. XII. 2003.

Cass., 12. VII. 2004.

Cass., 14. I. 2009.

Cass., 27981/11.

Cass., 49537/14.

C., Sez. un., 11. V. 1993.

C., Sez. I., 10. VI. 1986.

C., Sez. I., 12. VI. 2000.

C., Sez. II., 11. II. 1992.

C., Sez. III., 03. V. 1991.

C., Sez. III, 06. X. 1995. 
C., Sez. V., 13. I. 1999.

C., Sez. V., 26. II. 2008.

C., Sez. VI., 18. I. 1974.

C., Sez. VI., 24. XI. 1981.

C., Sez. VI., 08. III. 1995.

C., Sez. VI., 19. IX. 1995.

C., Sez. VI., 17. II. 1996.

C., Sez. VI., 26. III. 1997.

C., Sez. VI., 28. X. 1997.

C., Sez. VI., 19. I. 1998.

C., Sez. VI., 05. II. 1998.

C., Sez. VI., 02. VII. 1998.

C., Sez. VI., 24. IX. 1998.

C., Sez. VI., 07. I. 1999.

C., Sez. VI., 07. III. 2000.

C., Sez. VI., 16. XI. 2001.

C., Sez. VI., 21. III. 2003.

C., Sez. VI., 10. II. 2004.

C., Sez. VI., 30. XI. 2005.

C., Sez. VI., 06. II. 2007.

C., Sez. VI., 14. X. 2008.

C., Sez. VI., 02. IV. 2009.

C., Sez. VI., 25. III. 2010. 


\section{FUNDAMENTAL CHARACTERISTICS OF CRIMINAL LAW PROTECTION AGAINST CORRUPTION IN ITALIAN LEGISLATION, DOCTRINE AND COURT PRACTICE}

Policies of deterring the commission of crime, and especially acts of corruption including offering bribes as a typical act of that kind, is of particular importance for every regulated legal system. Criminal legal policy is at the centre of this policy. The entire political and economic development of every individual country depends to a great extent on the success of this policy

Contributing to the scientific discussion part, the criminal legislation of the Republic of Italy in regard to the issue of active bribery as one of the fundamental forms of corruptive behaviour is analysed in this paper. This is done with the aim of making the national criminal policy of combating corruptive criminal acts as effective as possible.

Demonstrating the comparative regulation of the Italian criminal system, which, like the Croatian one, belongs to European continental criminal legal systems, the author refers to the basic similarities and differences of the legal regulation of active bribery in the Republic of Italy in relation to the national legal system.

Key words: gift; bribes, other benefit; corruption; organized crime; public service; bribery; punishment; the purpose of punishment; penalty; imprisonment; criminal proceedings; criminal sanctions 